\title{
Population fluctuation and food preference of African snail by horticulture crops
}

\author{
Flutuação populacional e preferência alimentar \\ do caramujo-africano por culturas hortícolas
}

\author{
Lindinalva dos Santos ${ }^{1}$, Carla Ruth de Carvalho Barbosa-Negrisoli² (D), \\ Maciel Bispo dos Santos ${ }^{1}$, Aldomário Santo Negrisoli Junior ${ }^{3 *}$ (i)
}

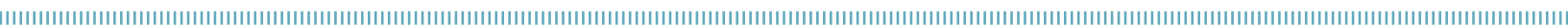

\begin{abstract}
The African snail Achatina fulica (Bowdich, 1822), originally from Africa, was introduced in Brazil and since then became an important pest, because of its resistance to abiotic conditions, hermaphroditism, polyphagia and absence of natural enemies. Considered as one of the 100 worst pests in the world, with the record of establishment in almost all Brazilian states, it causes sanitary, ecological and economic losses. In this context, the objective of this study was to determine the population dynamics and food preference of the giant snail in three areas of lettuce, located in Alagoas, Brazil. There was no statistical difference between food preference tests with and without choice among the varieties offered. To the fluctuation of the population of $A$. fulica, the Pearson correlation coefficients were negative only for temperature, and there was no correlation with precipitation and relative humidity.
\end{abstract}

KEYWORDS: Ecology, Lactuca sativa, Achatina fulica, management, mollusk.
RESUMO: O caramujo-africano Achatina fulica (Bowdich, 1822), originário da África, foi introduzido no Brasil e desde então se tornou uma praga importante, por sua resistência a condiçóes abióticas, hermafroditismo, polifagia e ausência de inimigos naturais. Considerada uma das cem piores pragas do mundo, com registro de implantaçáo em quase todos os estados brasileiros, causa perdas sanitárias, ecológicas e econômicas. Nesse contexto, o objetivo deste estudo foi determinar a dinâmica populacional e a preferência alimentar do caramujo-africano em três áreas de alface localizadas em Alagoas, Brasil. Não houve diferença estatística entre os testes de preferência alimentar com e sem escolha em meio às variedades oferecidas. Para a flutuação da população de $A$. fulica, os coeficientes de correlação de Pearson foram negativos apenas para a temperatura, não havendo correlação com a precipitação nem com a umidade relativa.

PALAVRAS-CHAVE: ecologia; Lactuca sativa; Achatina fulica; manejo; molusco. 


\section{INTRODUCTION}

Lettuce (Lactuca sativa L., Cichorieae) is the most consumed vegetable in Brazil and on the world. Being present in the domestic market and with economic importance in Brazil, it accounts for $11 \%$ of production, with 4,908,772 tons. Lettuce is normally produced in green belts, near to consumer centers (SANTOS et al., 2001), as the city of Arapiraca (Alagoas state, Brazil), that contributes to the improvement and expansion of public policy for horticulture. The city is also considered as the largest producer in the Alagoas state, providing lettuce to states of Pernambuco, Sergipe and Bahia. Inclement weather, as well as arthropods, microorganisms and other unwanted agents, can adversely affect physical and organoleptic quality of vegetables. In this sense, the giant African snail Achatina fulica (Bowdich, 1822) (Pulmonata: Achatinidae), introduced in Brazil in 1988 (TELES; FONTES, 2002), has caused invasions and it is present in all Brazilian states (OLIVEIRA et al., 2012).

The potential of $A$. fulica is favored by protandric hermaphroditism, i.e., young snails have only the male reproductive system and adults have both gonads, performing mutual copulation, fertilized with both individuals (TOMIYAMA; MIYASHITA, 1992). Each individual puts a lot of eggs (around 400 eggs per clutch) (FISCHER; COLLEY, 2005), with low energy allocation (TOMIYAMA, 1994). The adult carries out an average of five or six ovipositions a year, and sperm can be stored for more than 120 days, allowing incubation for dry periods (aestivation), with laying eggs so the weather conditions were favorable (RAUT; CHOSE, 1983).

According to RAUT; BARKER (2002), the sperm storage capacity provides species of Achatinidae ability to produce eggs in any season. After fertilization, the eggs in shell are kept internally and disposed at an advanced stage of embryonic development. The mature adult is approximately four months and longevity of three to five years. The young molluscs present dispersion every six months, while adults are considered more sedentary (TOMIYAMA; NAKANE, 1993), foraging during the daytime and resting at nighttime (TOMIYAMA, 1992). These gastropods, as well as other terrestrial molluscs, come into estivation for several months, during adverse weather periods, and tend to burrow into the soil (SIMONE, 1999) and form a protective layer, the epifragma, in order to temporarily close the opening of the shell, increasing the chance of survival. Even species living in rainforests may stow in the driest months (RAUT; BARKER, 2002).

Currently, this pest is adapted to both anthropogenic areas and natural environments, mainly in forests edges (up to $500 \mathrm{~m}$ ) (FISCHER; COLLEY, 2005), which probably favored its high adaptation and resistance to abiotic factors (temperature and humidity), as well as the competitive advantage with snails of similar sizes (RAUT; CHOSE, 1983). Other characteristics like as their fast dispersion and the population growth, high reproductive capacity, favorable resources and lack of predators in the country contribute for its severity (VENTURINI et al., 2008).

The giant African snail causes infestation in urban areas (gardens, vacant lots and garbage dump), destruction of ecosystems and hazard to human health due to transmission of diseases, besides the destruction of crops, ornamental plants and weeds (VENTURINI et al., 2008). Biological invasions are considered the second leading cause of biodiversity loss, as they may change the ecological cycles and homogenization of biota.

Despite several studies on these occupations, the lack of guidelines for the preparation of management programs that combine ecological theory and conservation practice has hindered the effectiveness of management actions (BYERS et al., 2002). However, it may still be involved in zoonoses associated with larvae of other veterinary importance nematodes, such as Aelurostrongylus abstrusus Railliet (Strongylida: Angiostrongylidae), parasites of cats, dogs, primates and badgers, also indicating its potential as intermediate host of other helminths (nematodes and trematodes) (OHLWEILER et al., 2010).

Considered as herbivorous generalist, the giant African snail can feed up to at least 500 species of crop plants of commercial interest (TELES et al., 2004), as: banana (Musa paradisiaca), beet (Beta vulgaris), calendula (Tagetes patula), cabbage and cauliflower (Brassica oleracea), Abelmoschus esculentus (L.) (Moench), pumpkin (Cucurbita pepo) and papaya (Carica papaya), and cucumber (Cucumis sativus).

This mollusk is the subject of intensive research, as evidenced in studies on metabolism and histology of the digestive gland (TUNHOLI-ALVES et al., 2015), toxicity of triclosan (WANG et al., 2014), constituents of cutaneous secretion (mucus) used in the development of biopharmaceuticals and in zootherapy (LORENZI; MARTINS, 2008).

Thus, the aims of this study were to record the occurrence of $A$. fulica, and to determine the population fluctuation in vegetables in three areas located in the green belt of Arapiraca, Alagoas, and its control in lettuce.

\section{MATERIALS AND METHODS}

\section{Collection and maintenance of Achatina fulica}

The study was carried from August 1, 2013, to May 28, 2014, in horticultural areas of the green belt of the city of Arapiraca (Alagoas, Brazil), in the regions of Bálsamo (09049'256";

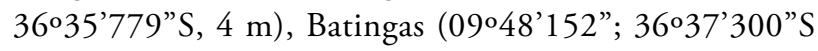
$126 \mathrm{~m}$ ) and Furnas (09048'680"; 036 $37^{\prime} 179^{\prime \prime} 8 \mathrm{~m}$ ). The type of crop system used was the conventional ( 0.30 between rows 
and $0.30 \mathrm{~m}$ between plants) without the application of pesticides or use of a control method of the snails.

The collections were conducted weekly, counting the number of $A$. fulica adults captured and subsequent incineration of the specimens in each sampled site, preventing recounting. Part of the collected individuals was sent to the laboratory, and those showed no symptoms of illness were created and used in laboratory bioassays. The $A$. fulica rearing was carried on plastic containers $(40 \times 30 \times 30 \mathrm{~cm})$ containing $1 \mathrm{~kg}$ of sterilized sand and fed with carrot, potato peel, besides being changed daily and cleaned every three days, kept at $25 \pm 1^{\circ} \mathrm{C}$. The separation between young and adults was made by size, with those between 2 and $10 \mathrm{~cm}$ considered young and adults more than $10 \mathrm{~cm}$ long. In the following tests, different amounts of individuals were used, because in preliminary observations it was established that the average capacity of consumption of two adults is equivalent to 12 young individuals. Before each bioassay, the snails were left by 24 hours without feeding.

\section{Non-choice test for food of Achatina fulica to plant varieties in the laboratory}

For the non-choice tests, plastic containers $(30 \times 20 \times 15 \mathrm{~cm})$ containing two sheets of filter paper to the bottom were used and offered as food bait, $15 \mathrm{~g}$ fresh weight of each plant variety. After 24 hours of exposure, the average consumption in grams for adults snail and heavy food debris in analytical balance was measured. Plant varieties of lettuce (Lactuca sativa L.) were crespa, americana, mimosa-roxa, mimosa-verde, besides chard (Beta vulgaris $\mathrm{L}$.), wild chicory (Cichorium endivia $\mathrm{L}$.), chives (Allium schoenoprasum L.), coriander (Coriandrum sativum L.), kale (Brassica oleracea var. acephala L.), peppermint (Mentha piperita L.), cabbage (B. oleracea var. capitata L.) and parsley (Petroselinum hortense L.). In each treatment, eight repetitions and two adult snails by repetition were considered. The bioassays were repeated twice, to confirm the data that were combined and presented on the results.

The experiment was completely randomized with 12 treatments and 10 repetitions, considering two snails by repetition. The mortality data of snail adults were subjected to analysis of variance and comparison of means using the Tukey test $(\mathrm{p}<0.05)$.

\section{Food preference test of Achatina fulica for plant varieties free choice in olfactometer in the laboratory}

For the free choice tests, olfactometers were built with circular plastic container (4 L) in the center, six branches (polyvinyl chloride pipe $40 \mathrm{~mm}$ ) with $30 \mathrm{~cm}$ long, connected to the central arena and six circular plastic containers $(200 \mathrm{~mL})$ (Fig. 1). In the center of the arena, 12 young snails (without food) were placed, and each branch of the olfactometer received $15 \mathrm{~g}$ of each treatment (substrate). After 24 hours of exposure, the average consumption in grams and the debris heavy in analytical balance were measured. The bioassays were repeated twice to confirm the data that were combined and presented on the results.

The experiment was completely randomized with 12 treatments and three repetitions, considering each olfactometer as a repeatition. Mortality data of snail were subjected to analysis of variance and comparison of averages using Tukey test $(\mathrm{p}<0.05)$.

\section{RESULTS AND DISCUSSION}

\section{Determination of the population dynamics of Achatina fulica in lettuce var. American in three regions of the green belt of Arapiraca, Alagoas, Brazil}

This is the first record of occurrence of the giant African snail A. fulica on lettuce in the regions in green belt Arapiraca, Alagoas. It was observed the presence of $A$. fulica in three sites throughout the period (from August 1, 2013, to May 28, 2014). A total number of 3,757 individuals were obtained, distributed in the regions of Batingas, Bálsamo and Furnas, with 160; 1,109 and 2,488 snails, respectively (Figs. 2, 3 and 4).

Agreeing with CIVEYREL; SIMBERLOFF (1996), this snail in adulthood is regarded as the one responsible for establishing the population of varying duration, population growth and homozygous. Moreover, OLIVEIRA et al. (2012) found in urban neighborhoods, located in Macapá, Brazil, lower amounts (578 individuals) to this study.

In Batingas, the number of individuals was lower (160 individuals) than in the other two areas, with the amount of snails always less than 30 individuals for collection (Fig. 2). The first population peak was observed at the beginning of August to early October; August; beginning of August to late October; and late January to late May 2014 for regions Balsamo, Batingas and Furnas, respectively (Figs. 2, 3, and 4).

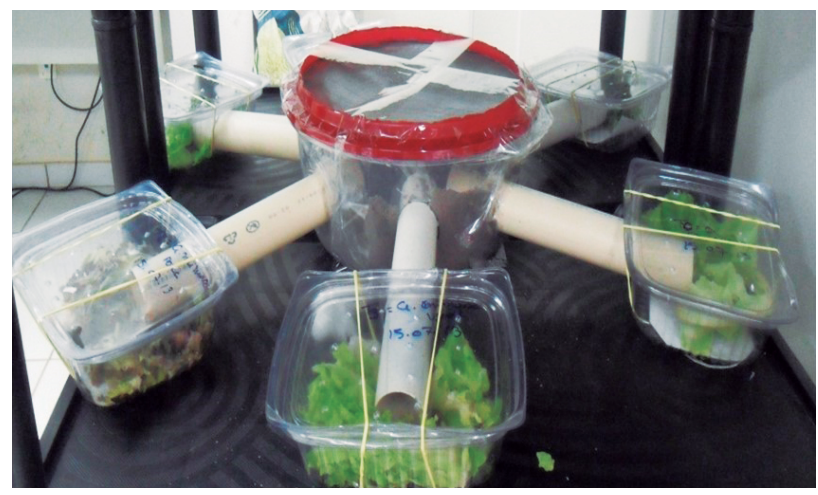

Figure 1. Olfactometer model used in bioassays. 
In general, the population peaks were observed in the periods from the beginning of August 2013, which corresponds to the rainy season, with high humidity and rainfall in the three regions sampled. On the other hand, the decline in the number of sampled snails occurred during the period of October 30, 2013, to January 22, 2014, corresponding to the high air temperature season, dry season in Furnas region (Figure 4). These observations corroborate studies in the state of Paraná, Brazil (FISCHER; COLLEY, 2005), assuming that A. fulica has a seasonal cycle of one or two generations per year, with copulations occurring mainly in spring and autumn. The evidence of seasonality and the effect of different environmental variables on A. fulica (MIRANDA et al., 2015) were recorded by several authors (RAUT; BARKER, 2002,
FISCHER; COLLEY, 2005), and demonstrate increased sexual activity when there are high humidity (heavy rains) and moderate temperatures (TOMIYAMA, 1994).

The vegetation cover tends to increase soil moisture (BURCH, 1957). There is a greater relationship between precipitation and sexual activity of $A$. fulica, as in months of higher rainfall, when there was higher percentage of sexually active snails in the metropolitan area of Salvador (Bahia, Brazil). The population fluctuation in annual abundance of $A$. fulica was also observed in other works, in India (RAVIKUMARA et al., 2007) and Rio de Janeiro, Brazil (May 2011 to April 2012) (ALMEIDA, 2013), with increase of population in June and peak in the second half of September. In general, terrestrial pulmonates tend to be more abundant in the rainy season, when the relative humidity and

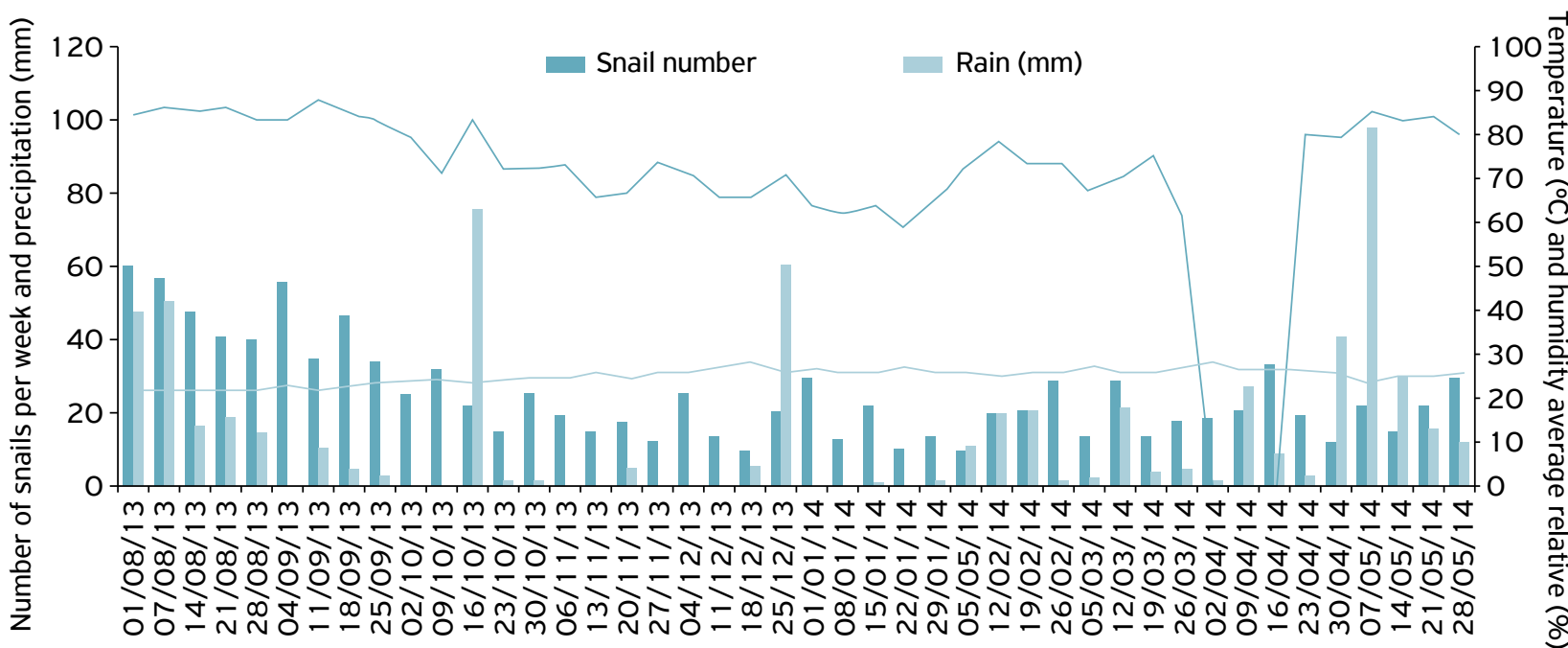

Figure 2. Weekly variation of adult of Achatina fulica collected from August 2013 to May 2014 in lettuce area (Lactuca sativa L.), in the location of Bálsamo, Arapiraca, Alagoas, Brazil.

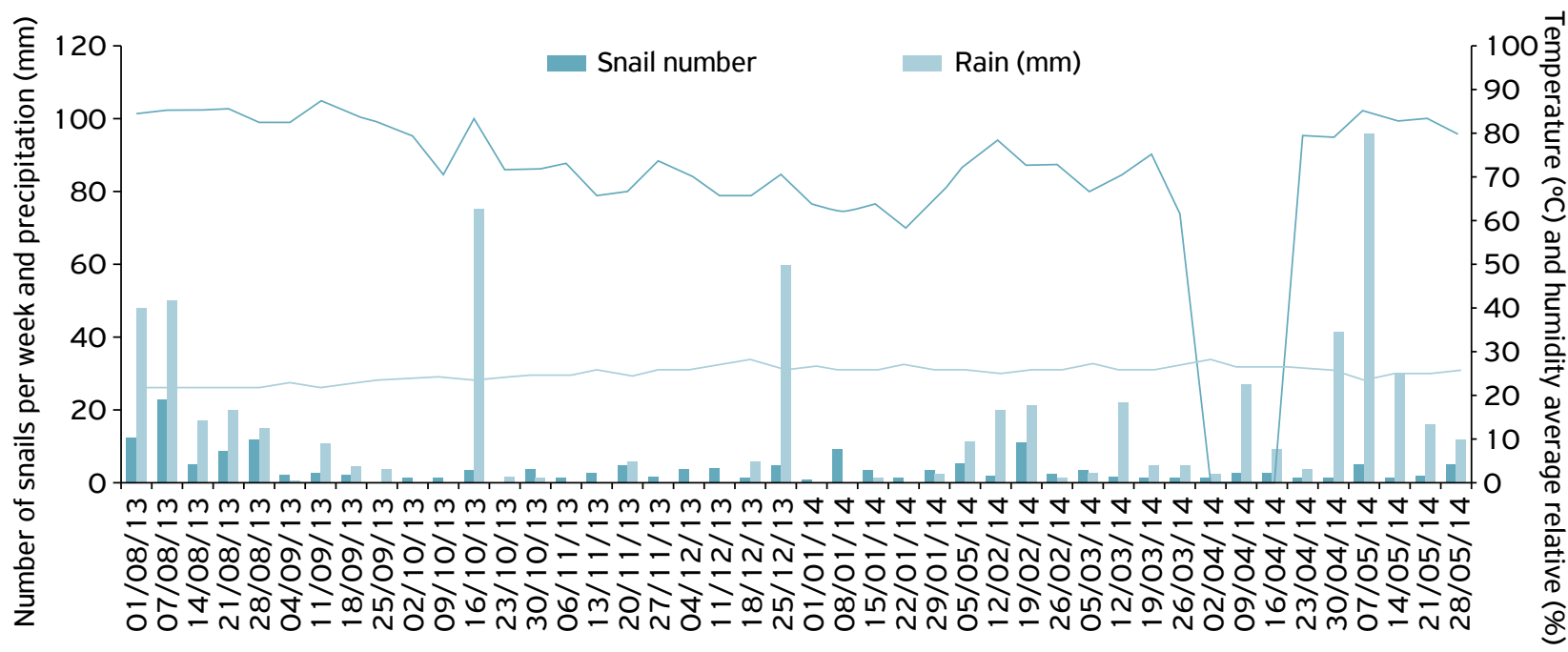

Figure 3. Weekly variation of adult of Achatina fulica collected from August 2013 to May 2014 in lettuce area (Lactuca sativa L.), in the location of Batingas, Arapiraca, Alagoas, Brazil. 
soil moisture are higher, showing the reproduction of interaction with the biotic and abiotic factors (TOMIYAMA, 1994).

On the other hand, ALMEIDA (2013) noticed increased abundance of $A$. fulica during inadequate periods of temperature and humidity, suggesting that may be a connection to the protective behavior that terrestrial gastropods exhibit to survive unfavorable periods. These animals lose water by the integument, but also hydrate the seed coat by rehydration by contact (COOK, 2001). Among some behavioral strategies that ensure survival during these inadequate periods are estivation, retraction cefalopedial mass inside the shell and into the soil or substrate as belonging to the family Subulinidae (ALMEIDA; MOTA, 2011). This behavior reduces the risk of desiccation, as the soil retains sufficient moisture to provide the survival of snail, as well as their burial is one of the main responses to temperature changes and moisture on the soil surface (ALMEIDA, 2013; MIRANDA et al., 2015).

The Pearson correlation coefficients were negative for the air temperature data $(-0.4558,-0.7439,-0.5125)$, while low correlation between the population of $A$. fulica and climatic variables, precipitation $(0.3772,0.1797,0.1598)$ and relative humidity $(0.2014,0.2568,0.1432)$ in the three areas, respectively, was verified. The negative correlation between the number of adults of $A$. fulica and the climate variable means as a factor which increases the other decreases and viceversa. Thus, other factors not assessed in this study probably were the responsible for the population difference of the pest among the three sites sampled.

The population of these snails decreased discreetly during the summer, when there is less precipitation, restricting the biological activity of these organisms. Since the environmental variables influencing the activity of $A$. fulica, interfering in population levels (MIRANDA et al., 2015) reported the effect of temperature interval as an important factor on $A$. fulica physiological status and thermal comfort. In addition, snails are very sensitive to drought, tending to restrict their movements, affecting the distribution and abundance in tropical forests.

Non-choice test for food of Achatina fulica to plant varieties in the laboratory

In non-choice test, the snails food preference expressed by all the vegetables used, with the highest and lowest consumption:

- coriander $(100 \%, 15 \mathrm{~g})$;

- $\quad$ chard (98.66\%, $14.8 \mathrm{~g})$;

- $\quad$ lettuce var. mimosa-verde $(98 \%, 14.7 \mathrm{~g})$;

- $\quad$ lettuce var. americana (94\%, $14.1 \mathrm{~g})$;

- $\quad$ lettuce var. mimosa-roxa (92\%, $13.8 \mathrm{~g})$;

- $\quad$ kale var. acephala $(66.66 \%, 10 \mathrm{~g})$;

- lettuce var. crespa $(60.66 \%, 9.1 \mathrm{~g})$;

- $\quad$ cabbage var. capitata $(52.66 \%, 7.9 \mathrm{~g})$;

- $\quad$ chicory $(36.66 \%, 5.5 \mathrm{~g})$;

- $\quad$ chives $(21.33 \%, 3.2 \mathrm{~g})$;

- $\quad$ peppermint, $(15.33 \%, 2.3 \mathrm{~g})$

- $\quad \operatorname{salsa}(5.33 \%, 0.8 \mathrm{~g})$.

There was no significant difference between treatments (Fig. 5), but there was evidence of a greater number of more preferred or more food substrates consumed (values above $50 \%$ consumption), than the less preferred or less consumed (values below $50 \%$ consumption).

According to FISCHER; COLLEY (2005), the vegetables as cabbage, lettuce, watercress, potato skins and chayote peel were that led to the foraging $A$. fulica, although there was variation in consumption, more preferably lettuce and arugula. Since the partial consumption of the food provided was significant for Japanese cabbage, watercress and kale leaf, $100 \%$ of the lettuce was consumed, confirming this study, although it was somewhat lower in both tests. In agreement with CAREFOOT; SWITZER-DUNLAP (1989), feed check occurs before and after ingestion, starting with the evaluation

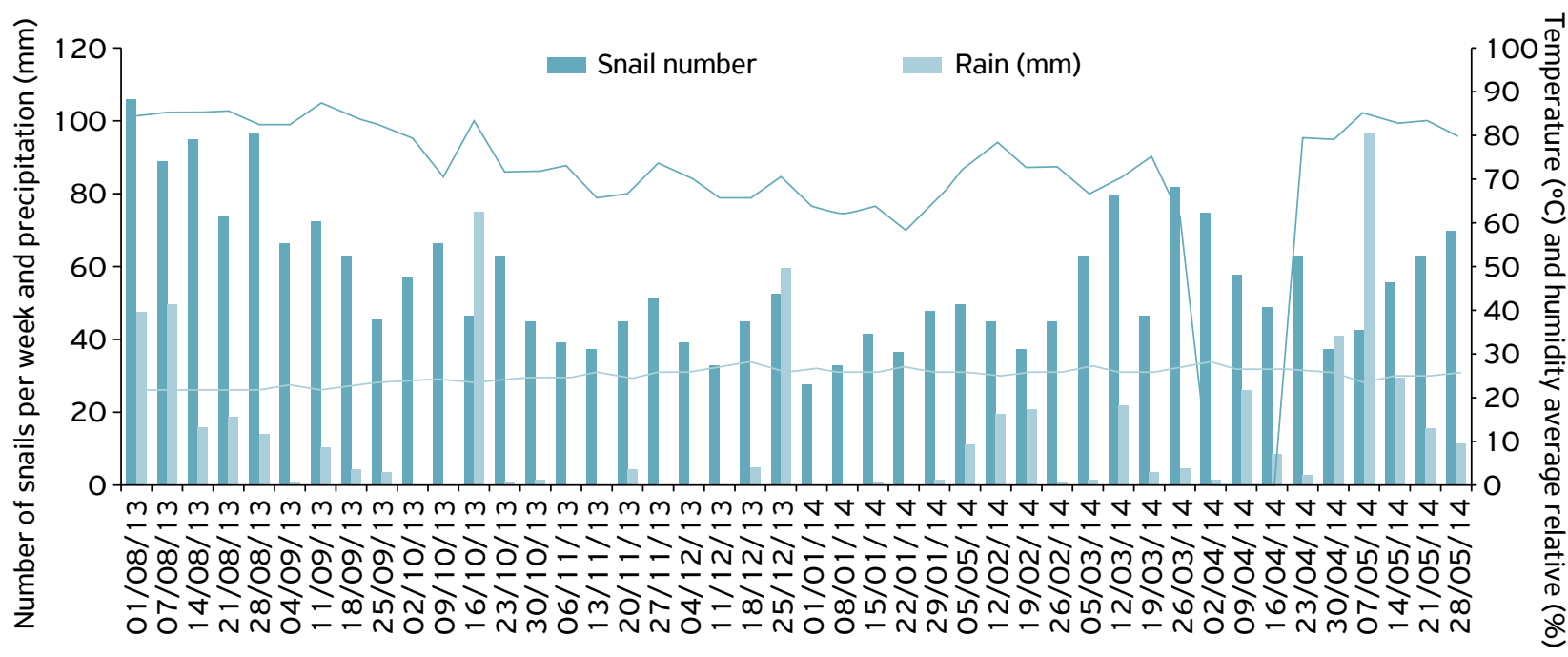

Figure 4. Weekly variation of adult of Achatina fulica collected from August 2013 to May 2014 in lettuce area (Lactuca sativa L.), in the location of Furnas, Arapiraca, Alagoas, Brazil. 
of odor and texture, palatability and handling, followed digestibility and nutrition, and the post-ingestion, the most important mechanism in learning aversion to unhealthy foods and determines future choices. Animals kept under restricted feeding have the same preferences than kept in diverse diets, suggesting genotypic influence on food preferences (RAUT; CHOSE, 1983; OGBU et al., 2014), corroborating the present study.

African snail has a long-term memory associating the food odors with their nutritional values, i.e., an animal which keeps 12 hours in contact with food after day rest period, direct itself to the same food the next phase of nocturnal activity (CHASE et al., 1980). These data corroborate this study.

The foods least consumed were parsley and peppermint. These qualitative and quantitative differences can be explained by many factors; among them, the nutritional property of each food. The feeding of $A$. fulica is dependent on the composition of the plant community (ALBUQUERQUE et al., 2008) and varies according to the quality and quantity (RAUT; BARKER, 2002). Some studies suggest that this may be a generalist snail (VINCI et al., 1988), as observed in Bahia state, Brazil (November 2001 to November 2002), where $A$. fulica fed species such as Hibiscus spp., Hemigraphis colorata (Blume), Cymbopogon citratus, Carica papaya, and Mentha spp. The location of the

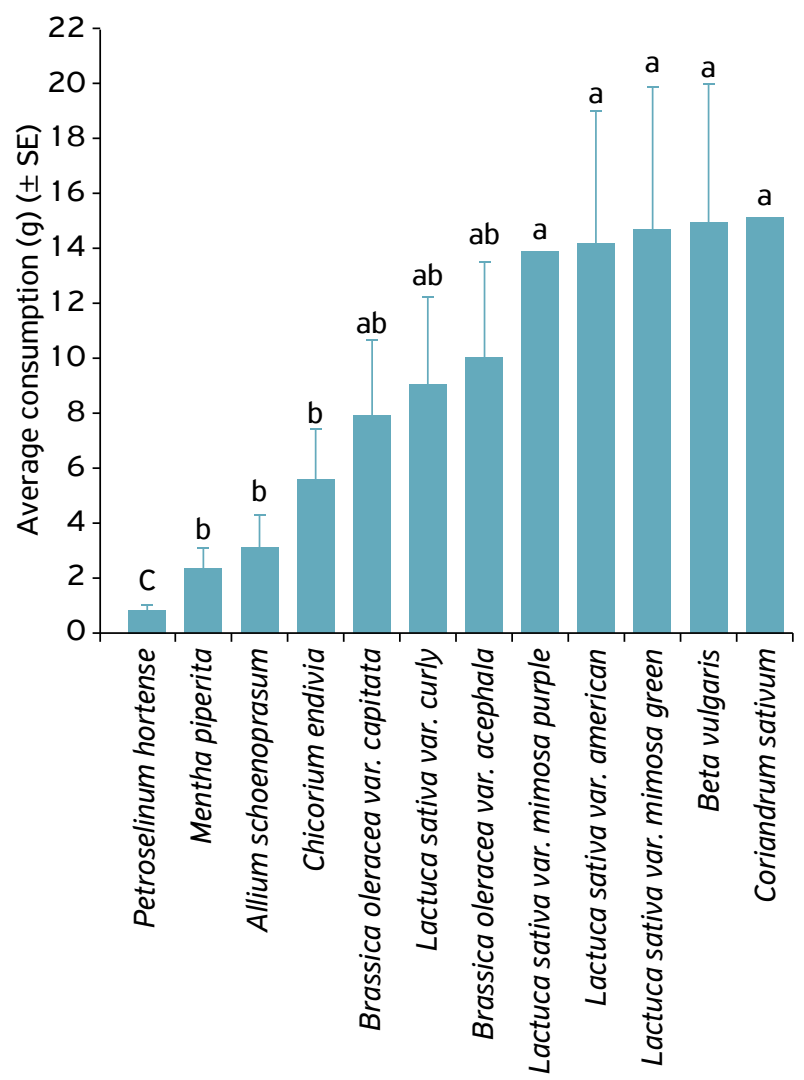

SE: standard error.

Figure 5. Average number of fresh food consumed by adult Achatina fulica in non-choice test at laboratory. food was due to the odor, with greater attraction for garden crops (FRANKIEL, 1989).

\section{Food preference test of Achatina fulica for plant varieties free choice in olfactometer in the laboratory}

Despite the species $A$. fulica is polyphagous, with a wide host range and great plasticity in their food (CHEVALIER et al., 2003), in food preference test with chance of choice, it was observed that these organisms had higher consumption of lettuce $(76.66 \% 11.5 \mathrm{~g})$ :

- variety crespa $(66.66 \%, 10 \mathrm{~g})$;

- variety mimosa-roxa $(65.33 \%, 9.8 \mathrm{~g})$;

- variety americana $(44 \%, 6.6 \mathrm{~g})$;

- variety mimosa-verde (Fig. 6).

Note that the foods more and less preferred of the previous experiment continued as more and less consumed by A. fulica in this experiment, respectively. Results contrary to this study were observed by CHEVALIER et al. (2003), that found out that $30 \%$ of Helix aspersa showed no feeding activity. Studies of preferences and exploitation of feed in the field

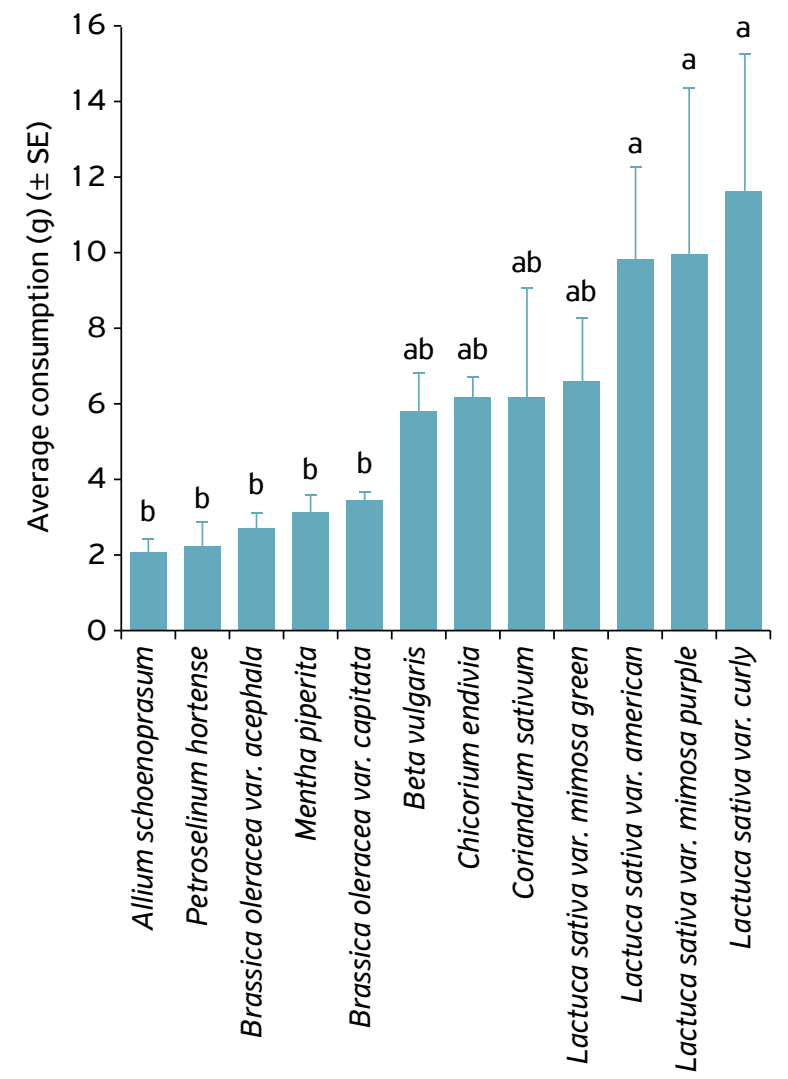

SE: standard error.

Figure 6. Average number of fresh matter consumed by adult Achatina fulica in food preference test with chance of choice, olfactometer. 
(CHEVALIER et al., 2003) have demonstrated the ability of snails in choosing their food when they are free to choice and to keep the food preference memories. Studies on learning and memory of $A$. fulica and $A$. marginata were described by CHEVALIER et al. (2003).

The development of food preferences in animals has been linked to post-digestive effects (satiety or malaise) and their interaction, especially with the senses of taste and smell (KIMBERLY; SALICE, 2012). The concept of food preference comprises two features: attractiveness (measured by tests with and without free choice) and palatability (measured by comparing the amount of different food eaten by the animal under study) (OGBU et al., 2014), that distinguish appetite from non-appetite, a fact which corresponds to the present study. According to these authors, this may be related to the selective behavior of animals when fed free choice, because animals often prove all feeds provided before settling down as the most nutritious (preferred) (OGBU et al., 2014), as found in this study.

Just as verified by ALBUQUERQUE et al. (2008), all food (leaves of vascular plants) were preferred by adults of A. fulica (Hibiscus syriacus, Ricinus communis, Carica papaya,
Galinsonga coccinea, Lippia alba, Ixora coccinea, Musa paradisiaca, Mentha spicata and Cymbopogon citratus), in test feeding behavior in vessel under laboratory conditions. According to RAUT; CHOOSE (1983), A. fulica prefers ornamentals plants because they are very juicy and also litter, reinforced by SANTOS et al. (2002), which latter is comprised of decaying vegetable matter, which facilitates the feeding of snail. RAUT; CHOSE (1983) state that the most terrestrial molluscs prefer dead leaves, because the bacteria and fungi break down the cellulosic wall; besides the A. fulica has a odontophore gentle.

\section{CONCLUSIONS}

The African snail is present throughout the sample period in the sampled sites. Curly lettuce, iceberg lettuce, purple lettuce mimosa, mimosa green lettuce, chard, chicory, chives, coriander, kale, peppermint, cabbage and parsley (unknown varieties) are consumed by $A$. fulica in preference in choice and non-choice tests.
ALBUQUERQUE, F.S.A.; PESO-AGUIAR, M.C.B; ASSUNÇÃOALBUQUERQUE, M.J.T. Distribution, feeding behavior and control strategies of the exotic land snail Achatina fulica (Gastropoda: Pulmonata) in the northeast of Brazil. Brazilian Journal of Biology, v.68, n.4, p.837-842, 2008. http://dx.doi.org/10.1590/ S1519-69842008000400020

ALMEIDA, M.N. Abundância, sazonalidade, reprodução e crescimento da concha de uma população de Achatina fulica [Bowdich, 1822] [Mollusca, Achatinidae] em ambiente urbano. Arquivos de Ciências Veterinárias e Zoologia, v.16, n. 1, p.51-60, 2013. DOI: https://doi.org/10.25110/arqvet. v16i1.2013.4484

.: MOTA, G.G. Ecologia, reprodução e crescimento da concha de Beckianum beckianum Pfeiffer, 1846 (Pulmonata, Subulinidae) em condições naturais. Revista de Biologia e Farmácia, v.6, n. 1, 75-85, 2011.

BURCH, J.B. Distribution of Land Snails in plant association in eastern Virginia. The Nautilus, v.70, p.606-640, 1957.

BYERS, J.E.; REICHARD, S.; RANDALL, J.M.; PARKER, I.M.; SMITH, C.S.; LONSDALE, W.M.; ATKINSON, A.E.; SEASTEDT, T.R.; WILLIAMSON, M.; CHORNESKY, E.; HAYES, D. Directing research to reduce the impacts of nonindigenous species. Conservation Biology, v.16, n.3, p.630-640, 2002. https://doi. org/10.1046/j.1523-1739.2002.01057.x
CAREFOOT, T.H.; SWITZER-DUNLAP, M. Effect of amino acid imbalance in artificial diets on food choice and feeding rates in two species of terrestrial snails Cepaea nemoralis and Achatina fulica. Journal of Molluscan Studies, v.55, n.3, p.323-328, 1989. DOI: 10.1093/mollus/55.3.323

CHASE, R.; CROLL, R.P.; ZEICHNER, L.L. Aggregation in snails, Achatina fulica. Behavioural and Neural Biology, v.30, n.2, p.218230, 1980. https://doi.org/10.1016/SO163-1047(80)91101-2

CHEVALIER, L.; LE COZ-BOUHNIK, M.; CHARRIER, M. Influence of inorganic compounds on food selection by the brown garden snail Cornu aspersum (Muller) (Gastropoda: Pulmonata). Malacologia, v.45, n. 1, p. $125-132,2003$.

CIVEYREL, L.; SIMBERLOFF, D. A tale of two snails: is the cure worse than the disease? Biodiversity and Conservation, v.5, n. 10 , p.1231-1252, 1996. https://doi.org/10.1007/BF00051574

COOK, A. Behavioural ecology: on doing the right thing, in the right place at the right time. In: BARKER, G.M. (Ed). The biology of terrestrial molluscs. Trowbridge: CABI Publishing, 2001. p.447-487.

FISCHER, M.L.; COLLEY, E. Espécies invasoras em reservas naturais: caracterização da população de Achatina fulica Bowdich, 1822 (Molusca-Achatinidae) na ilha Rasa, Guaraqueçaba, Paraná, Brasil. Biota Neotropica, v.5, n. 1, p.127-144, 2005. http://dx.doi. org/10.1590/S1676-06032005000100014 
FRANKIEL, L. The Achatines in the Antilles. France. Circular. In: GALLOIS, L.; DAGUZAN, J. (Eds.), Recherches écophysiologiques sur le régime alimentaire de l'escargot petitgris (Helix aspersa Müller) (Mollusque Gasteropode Pulmoné Stylommatophore). Haliotis, v.19, p.77-86, 1989.

KIMBERLY, D.A.; SALICE, C.J. Dietary acclimation affects dietary selection in the freshwater snail, Planorbella trivolvis. Journal of Molluscan Studies, v.78, n.3, p.256-261, 2012. https://doi. org/10.1093/mollus/eys013

LORENZI, A.T.; MARTINS, M.F. Análise colorimétrica e espectroscópica do muco de caracóis terrestres Achatina sp alimentados com ração diferenciada. Revista Brasileira de Zootecnia, v.37, n.3, p.572-579, 2008. http://dx.doi.org/10.1590/ S1516-35982008000300024

MIRANDA, M.S.; FONTENELLE, J.H.; PECORA, I.L. Population structure of a native and an alien species of snail in an urban area of the Atlantic Rainforest. Journal of Natural History, v.49, p.19-35, 2015. doi: 10.1080/00222933.2014.930756

OGBU, C.C.; ANI, A.O.; EMEH, M. Feed preferences and feeding behaviour of two species of african giant land snails. Archivos de Zootecnia, v.63, n.242, p.337-347, 2014. DOI: 10.4321/ s0004-05922014000200012

OHLWEILER, F.P.; GUIMARÃES, M.C.A.; TAKAHASHI, F.Y.; EDUARDO, J.M. Current distribution of Achatina fulica, in the state of São Paulo including records of Aelurostrongylus abstrusus (Nematoda) larvae infestation. Revista do Instituto de Medicina Tropical de São Paulo, v.52, n.4, p.211-214, 2010. http://dx.doi.org/10.1590/ s0036-46652010000400009

OLIVEIRA J.C.S.; GONÇALVES, T.S.; MONTEIRO, P.R.; SARAIVA, I.O.; VASCONCELOS, H.C.G. Ocorrência de Achatina fulica (Mollusca: Pulmonata: Achatinidae) em três bairros da cidade de Macapá, Amapá. Biota Amazônia, Macapá, v.2, n.2, p.78-81, 2012. DOI: http://dx.doi.org/10.18561/2179-5746/biotaamazonia. v2n2p $78-81$

RAUT, S.K.; BARKER, G.M. Achatina fulica Bowdich and other Achatinidae as Pests in Tropical Agriculture. In: BARKER, G.M. (Ed). Molluscs as Crop Pests New Zealand: CAB Publishing, 2002. p. 55-114.

; CHOSE, K.C. Food preferences and feeding behavior in two land snails, Achatina fulica Bowdich and Macrochlamys indica Godwin-Austen. Records of the Zoological Survey of India, v.80, p.421-440, 1983.

RAVIKUMARA, N.; MANJUNATH, M.I.M.; PRADEEP, S. Seasonal incidence of giant african snail, Achatina fulica Bowdich (Gastropoda: Achatinidae) in Areca Ecosystem. Karnataka Journal of Agricultural Sciences, v.20, n.1, p.157-158, 2007.

SANTOS, R.H.; SILVA, F.; CASALI, V.W.D.; CONDE, A.R. Efeito residual da adubação com composto orgânico sobre o crescimento e produção de alface. Pesquisa Agropecuária Brasileira, v.36, n. 11 , p.1395-1398, 2001. http://dx.doi.org/10.1590/ so $100-204 \times 2001001100010$

SANTOS, S.B.; MONTEIRO, D.P.; THIENGO, S.C. Achatina fulica (Mollusca: Achatinidae) na llha Grande, Angra dos Reis, Rio de Janeiro: implicações para a saúde ambiental. Biociências, v.10, p.159-162, 2002.

SIMONE, L.R.L. Mollusca Terrestres. In: BRANDÃO, R.F.; CANCELLO, E.M. (Eds.). Invertebrados terrestres: biodiversidade do Estado de São Paulo, Brasil. v. 5. São Paulo: FAPESP, 1999. p. 3-8.

TELES, H.M.S.; FONTES, L.R.; AMARAL, W. Pesquisa nacional de opinião pública sobre a espécie do caramujo Achatina fulica. $\mathrm{n}$. 01. v. 24. Atibaia: Instituto Brasileiro de Helicicultura - IBH/ CEDIC, 2004.

Implicações da introdução e dispersão de Achatina fulica Bowdich, 1822 no Brasil. Boletim do Instituto Adolfo Lutz, v.12, p.3-5, 2002.

TOMIYAMA, K. Homing behavior of the giant African snail, Achatina fulica (Férussac) (Gastropoda; Pulmonata). Journal of Ethology, v.10, n.2, p.139-146, 1992.

.; NAKANE, M. Dispersal patterns of the giant African snail, Achatina fulica (Férussac) (Stylommatophora: Achatinidae), equipped with a radiotransmitter. Journal of Molluscan Studies, v.59, n.3, p.315-322, 1993.

TOMIYAMA, K. Courtship behaviour of the Giant African snail, Achatina fulica (Férussac) (Stylommatophora; Achatinidae) in the field. Journal of Molluscan Studies, v.60, n. 1, p.47-54, 1994. https://doi.org/10.1093/mollus/60.1.47

TOMIYAMA, K.; MIYASHITA, K. Variation of egg clutches in the Giant African snail, Achatina fulica (Ferussac) (Stylommatophora: Achatinidae). Venus, v.51, n.4, p.293-301, 1992.

TUNHOLI-ALVES, V.M.; TUNHOLI, V.M.; AMARAL, L.S.; MOTA E.M.; MALDONADO JUNIOR, A.; PINHEIRO, J.; GARCIA, J. Biochemical profile of Achatina fulica (Mollusca: Gastropoda) after infection by different parasitic loads of Angiostrongylus cantonensis (Nematoda, Metastrongylidae). Journal of Invertebrate Pathology, v. 124, 1-5, 2015.

VENTURINI, F.P.; CRUZ, C.; PITELLI, R.A. Toxicidade aguda do sulfato de cobre e do extrato aquoso de folhas secas de nim para o caramujo (Pomacea canaliculata). Acta Scientiarum. Biological Sciences, v.30, n.2, p.179-184, 2008. http://dx.doi. org/10.4025/actascibiolsci.v30i2.3615

VINCI, G.K.; UNNITHAN, V.K.; SUGUNAN, V.V. Farming of the Giant African Snail, Achatina fulica. India: Central Inland Capture Fisheries Research Institute, 1988. n. 56, p. 1-24.

WANG, X.; LIU, Z.; WANGA, W.; YAN, Z.; ZHANG, C.; WANG, W.; CHEN, L. Assessment of toxic effects of triclosan on the terrestrial snail (Achatina fulica). Chemosphere, v.108, p.225-230, 2014. doi: 10.1016/j.chemosphere.2014.01.044 